\title{
Association analysis of the glucocorticoid receptor gene (NR3C1) haplotypes (ER22/23EK, N363S, BclI) with mood and anxiety disorders in patients with asthma
}

\author{
MICHAŁ PANEK ${ }^{1}$, TADEUSZ PIETRAS ${ }^{2}$, JANUSZ SZEMRAJ $^{3}$ and PIOTR KUNA ${ }^{1}$ \\ Departments of ${ }^{1}$ Internal Medicine, Asthma and Allergy, ${ }^{2}$ Pneumology and Allergology and \\ ${ }^{3}$ Medical Biochemistry, Medical University of Łódź, Łódź, Łódź Voivodeship 90-153, Poland
}

Received December 2, 2013; Accepted May 8, 2014

DOI: $10.3892 /$ etm.2014.1734

\begin{abstract}
Chronic inflammation in the bronchi of long-term asthma patients worsens mood disorders, which has been shown to correlate with elevated levels of multiple proinflammatory cytokines. The glucocorticoid receptor (GR) gene, NR3Cl, plays a key role in the control of inflammation. Disturbances in the structure and function of the GR alter the glucocorticoid regulation of the corticotropin-releasing hormone, which leads to nonspecific activation of numerous receptors in the brain and alters the metabolism. The aim of the present study was to evaluate the role of $N R 3 C 1$ haplotypes in mood and anxiety disorders. The study included 235 patients with asthma and 216 healthy individuals. Genotyping of NR3C1 gene polymorphisms was performed using polymerase chain reaction-restriction fragment length polymorphism. Beck's Depression Inventory, State and Trait Anxiety Inventory tests and the Borg scale were applied for all the subjects. Significant differences in the levels of depression $(\mathrm{P}=0.000008)$ and dyspnea $(\mathrm{P}=0.000001)$ were observed between the patients and healthy subjects. In addition, a correlation was identified between spirometric parameters and the intensity of depression, anxiety and subjective dyspnea. The AA ER22/23EK, AA N363S and CC BclI haplotype of the NR3Cl gene was identified to significantly aggravate trait anxiety in patients with asthma $(\mathrm{P}=0.026)$. Therefore, the $N R 3 C 1$ gene substantially modified the level of trait anxiety in asthma sufferers.
\end{abstract}

\section{Introduction}

Affective disorders and obstructive diseases, including asthma and chronic obstructive pulmonary disease (COPD),

Correspondence to: Dr Michał Panek, Department of Internal Medicine, Asthma and Allergy, Medical University of Łódź, 22 Kopcińskiego, Łódź, Łódź Voivodeship 90-153, Poland

E-mail: michalmp@poczta.onet.pl

Key words: glucocorticoid receptor gene $N R 3 C 1$, inflammation, asthma, depression, anxiety, breathlessness are becoming more frequent (1). The growth in the number of asthma sufferers has increased with the incidence of mood disorders, including asthma and mood disorder, both, dependent on genetic and environmental factors. There is a significant prevalence of depression in daily life with $7-12 \%$ of males and $20-25 \%$ of females affected, and an annual occurrence of $6-12 \%$ in the adult population. Females are two or three times more likely to suffer from depression compared with males, and the probability of depression recurring after treatment during a lifetime is as high as $80 \%$ (1). The relative occurrence of mood disorders in the course of obstructive disease is 1.7 times greater in asthma sufferers [95\% confidence interval (CI), 1.1-2.3] and 1.9 times greater in patients with COPD (95\% CI, 1.2-2.1) (2). In the stable phase of COPD, depression affects between 15 and $42 \%$ of patients, while mood disorders affect 10-19\% (3). Mild depression is estimated to occur in $26 \%$ of mild asthma sufferers and moderate symptoms of depression may be present in $36 \%$ of individuals with moderate asthma (4).

Depression and anxiety, as components of personality, are to a certain degree conditioned by temperament, which is a natural predisposition of human emotional reactivity. Temperament is manifested in the formal elements of behavior; the reaction of a person to stress and their behavior in extreme situations depends indirectly on their temperament. Certain elements of temperament predispose the patient to the development of disorders in their psyche, including depression and anxiety, and behavior (5-7).

Psychosomatic factors play a significant role in the pathogenesis of asthma (8). Mood and anxiety disorders are more common in patients with obstructive disorders compared with healthy control groups. Stress, such as that encountered when not carrying an inhaler, may cause psychogenic dyspnea, which is demonstrated by a positive association existing between the functional parameters of the flow-volume curve and the subjective sense of dyspnea and anxiety (4).

There are several important mechanisms that induce mood disorders in asthma, including common genetic factors, certain drugs used to treat obstruction and inflammatory mediators (cytokines) that modify the metabolism of the brain. Moreover, asthma as a chronic inflammatory airway disease acts as a stressor (4,9-13). 
Asthma is a chronic inflammatory disease of the respiratory tract that exacerbates mood disorders and is correlated with the concentration of a number of inflammatory markers, including C-reactive protein, interleukin (IL)-5, -6 and -12 , tumor necrosis factor- $\alpha$ and interferon- $\alpha$ (10-12). Inflammatory mediators cause a secondary decrease in the activity of the cAMP response element-binding and tyrosine kinase transforming proteins, resulting in impaired secretion of brain-derived neurotrophic factor in the frontal lobes and limbic system $(12,14-16)$. As a consequence of these reactions, the hippocampus becomes damaged and a there is a reduced concentration of monoamines in the brain $(14,17)$. Certain cytokines are able to activate multiple signaling pathways with the activation of janus kinase (JAK) 2 and STAT5. The JAK-STAT signaling pathway plays an important role in cell proliferation and survival in the central nervous system (CNS). The pathway also affects the cell response to various hormones, growth factors and cytokines $(18,19)$. Activation of the JAK-STAT pathway leads to the development of depressive effects via glucocorticoid (GC) signaling (20).

Hyperactivity of the well characterized hypothalamic-pituitary-adrenal (HPA) axis, plays an important role in the pathogenesis of affective disorders in asthma. In addition, corticotrophin-releasing hormone (CRH) hyperactivity causes disorders in the proper functioning of the CNS, due to impaired negative regulation of CRH by GCs (21-23). This altered regulation of CRH by GCs is caused by disturbances to the structure and function of the GC receptor (GR) $(23,24)$. Numerous studies have demonstrated the crucial role played by polymorphic forms of the gene coding for the GR, NR3Cl, in the regulation of $\mathrm{CRH}(25-29)$. Changes in the nucleotide sequence by single nucleotide polymorphisms (SNPs) may influence expression and lead to changes in RNA assembly. Polymorphisms are responsible for the modification of the secondary and tertiary structure of GR domains, and cause disorders in the initiation and stability of mRNA transcription for GRs $(25,26,28,30,31)$. The BclI (rs41423247) and N363S (rs6195) polymorphisms of the NR3Cl gene increase the sensitivity of the GCs, while the ER22/23EK SNP (rs6189/rs6190) is associated with resistance to GCs $(28,32,33)$.

Therefore, the aims of the present study were twofold: Firstly, to determine whether correlations exist between the levels of depression and anxiety and more objective measures of airflow obstruction in asthma patients, and secondly, to confirm whether the genetic determinant of NR3C1 significantly affects these factors.

\section{Patients and methods}

Ethical approval. The study was approved by the local Ethics Committee (Consent of Research Review Board of the Medical University of Łódź, Łódź, Poland; no. RNN/133/09/KE). At the start of the study, participants were invited to attend voluntarily and prior to enrollment, written informed consent was obtained from every patient.

Patient selection. A total of 235 patients with bronchial asthma were recruited for the study. Asthma diagnosis was established according to the Global Initiative For Asthma recommendations, based on clinical asthma symptoms and lung function tests. The level of asthma severity and control was determined according to the American Thoracic Society (ATS) guidelines (34). Apart from a subjective examination, structured anamnesis was performed and a number of factors were examined, including gender, obesity, tobacco smoking, duration of bronchial asthma, allergy to house dust mites, animal fur, mould spores, cockroach allergens and hypersensitivity to nonsteroidal anti-inflammatory drugs $(25,26)$.

The exclusion criteria included subjects suffering from clinically significant exacerbations, or who were using drugs, such as rifampicin, phenobarbital, phenytoin or ephedrine, which may induce resistance to GCs. Subjects with signs of viral infections, generalized or affecting the respiratory tract, as well as those failing to comply with the recommendations of their doctor, were also excluded. The control arm included a group of 216 healthy adults who met the following criteria: No history or symptoms of bronchial asthma, other pulmonary diseases, allergy, atopic dermatitis and hypersensitivity to aspirin; negative skin tests results for 12 common allergens; and no first-degree relatives with bronchial asthma or atopic disorders. Healthy volunteers were selected on a random basis from the general population $(25,26)$.

In the bronchial asthma group, $62.6 \%$ (147) of the patients were female and $37.4 \%$ (88) were male. The average age was 48.8 \pm 16.0 years (range, 19-82 years; median, 51 years; mode, 52 years). The average forced expiratory volume in $1 \mathrm{sec}$

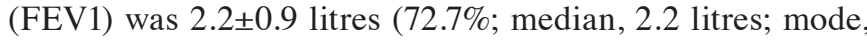
2.4 litres) and the average forced vital capacity (FVC) was 3.3 \pm 1.1 litres (91.4\%; median, 3.2 litres; mode, 2.3 litres).

The control group comprised 216 healthy individuals: $65.7 \%$ (142) females and $34.3 \%$ (74) males. The average age was $45.7 \pm 16.3$ years (range, 18-85 years; median, 47 years; mode, 23 years). The average FEV1 was 3.0 0.8 litres (96.1\%; median, 2.9 litres; mode, 2.7 litres) and the average FVC was 3.8 \pm 1.0 litres (102.7\%; median, 3.6 litres; mode, 3.5 litres).

Detailed descriptive statistics for age and spirometric parameters for the cases and controls are presented in Table I.

Functional assessments. Functional assessments of the respiratory system were conducted according to the European Respiratory Society and ATS standards (34).

In all the tests, the Polish language version of the Beck Depression Inventory was used (35-37), where results were expressed as a total number of the points obtained. Trait and state anxieties were measured using the Polish language adaptation of Spielberg's State and Trait Anxiety Inventory (STAI) (37,38), where the results were expressed as absolute numbers of the points obtained. The level of declared breathlessness was estimated on the 10-point Borg scale of subjective feelings (37,39). Each patient recorded their subjective impression of breathlessness at the time of the test on a scale of 0-10 (37).

Sample collection. Venous blood samples were collected from the participants and placed into K3-EDTA tubes. DNA was obtained from the peripheral blood leukocyte fraction and isolated using a QIAamp DNA Blood Mini kit (Qiagen, Hilden, Germany), according to the manufacturer's instructions. Polymorphisms were analyzed using polymerase chain reaction-restriction fragment length polymorphism (PCR-RFLP). 
Table I. Descriptive statistics for age and spirometric parameters in the healthy control subjects and asthma patients.

\begin{tabular}{|c|c|c|}
\hline Parameter & $\begin{array}{c}\text { Bronchial } \\
\text { asthma group }\end{array}$ & $\begin{array}{c}\text { Control } \\
\text { group }\end{array}$ \\
\hline Subjects (n) & 235 & 216 \\
\hline Females (\%) & 62.6 & 65.7 \\
\hline Males (\%) & 37.4 & 34.3 \\
\hline \multicolumn{3}{|l|}{ Age (years) } \\
\hline Average & 48.8 & 45.7 \\
\hline $\mathrm{SD}$ & \pm 16.0 & \pm 16.3 \\
\hline Minimum & 19 & 18 \\
\hline Maximum & 82 & 85 \\
\hline Median & 51.0 & 47.0 \\
\hline Mode & 52.0 & 23.0 \\
\hline \multicolumn{3}{|l|}{ FEV1 } \\
\hline Average (litre) & 2.2 & 3.0 \\
\hline Average (\%) & 72.7 & 96.1 \\
\hline SD (litre) & \pm 0.9 & \pm 0.8 \\
\hline Median (litre) & 2.2 & 2.9 \\
\hline Mode (litre) & 2.4 & 2.7 \\
\hline \multicolumn{3}{|l|}{ FVC } \\
\hline Average (litre) & 3.3 & 3.8 \\
\hline Average (\%) & 91.4 & 102.7 \\
\hline SD (litre) & \pm 1.1 & \pm 1.0 \\
\hline Median (litre) & 3.2 & 3.6 \\
\hline Mode (litre) & 2.3 & 3.5 \\
\hline
\end{tabular}

$\mathrm{SD}$, standard deviation; FEV1, forced expiratory volume in $1 \mathrm{sec}$; FVC, forced vital capacity.

$P C R$. Exponential amplification of the DNA segments for the ER22/23EK polymorphism was conducted using forward (5'-TGC ATT CGG AGT TAA CTA AAA AG-3') and reverse (5'-ATC CCA GGT CAT TTC CCA TC-3') primers, according to a standard PCR protocol. Starter binding to complementary DNA matrix sites was conducted at $56^{\circ} \mathrm{C}$. Amplified DNA sequences of $448 \mathrm{bp}$ were obtained. The genetic material was incubated with the $M n l \mathrm{I}$ restriction enzyme (Fermentas International, Inc., Burlington, Canada) at $37^{\circ} \mathrm{C}$ for $20 \mathrm{~h}$ (40). DNA fragments of 149 and $163 \mathrm{bp}$, and shorter fragments containing 50, 49 and $35 \mathrm{bp}$, were obtained as a set of representative, typical (wild type) alleles, whereas segments of 163 and $184 \mathrm{bp}$, and shorter fragments containing 50 and $49 \mathrm{bp}$, constituted the set of polymorphic alleles $(26,40)$.

Exponential amplification of the DNA segments for the N363S polymorphism was performed using forward (5'-CCA GTA ATG TAA CAC TGC CCC-3') and reverse (5'-TTC GAC CAG GGG AAG TTC AGA-3') primers, according to a standard PCR protocol (41). Starter binding to complementary DNA matrix sites was conducted at $56^{\circ} \mathrm{C}$ and amplified DNA sequences of $357 \mathrm{bp}$ were obtained. The material was incubated with FastDigest ${ }^{\circledR}$ Tsp509I (TasI) restriction enzyme (Fermentas International, Inc., Burlington, Canada) at $65^{\circ} \mathrm{C}$ for $1 \mathrm{~h}$ (40). DNA fragments of 135, 73, 70, 60 and $19 \mathrm{bp}$ were obtained as a set of representative, typical (wild type) alleles, whereas segments of 135, 92 (73 and 19 bp), 70 and $60 \mathrm{bp}$ constituted the set of polymorphic alleles $(25,41)$.

Amplification of the DNA fragment containing the BclI polymorphism of the NR3Cl gene was conducted using starters with the following sequences: Forward, 5'-GAG AAA TTC ACC CCT ACC AAC-3' and reverse (5'-AGA GCC CTA TTC TTC AAA CTG-3', according to a standard PCR protocol (42). Starter binding to complementary DNA matrix sites was conducted at $56^{\circ} \mathrm{C}$. The $\mathrm{Bcl}$ I restriction enzyme (Fermentas International, Inc.) was used for the digestion of the amplification product containing the $B c 1$ I polymorphism (40). Hydrolysis of the PCR product with the restriction enzyme was conducted for $24 \mathrm{~h}$ at $55^{\circ} \mathrm{C}$. DNA fragments containing 263 and $151 \mathrm{bp}$ were identified as a set of representative, typical (wild type) alleles, as well as segments with 418, 263 and $155 \mathrm{bp}$. An RFLP product, 418 bp in length, was identified as a set of polymorphic alleles (40).

For each of the SNP tests, representative, typical homozygotes and heterozygotes were sequenced and used as internal controls. Following restriction enzyme digestion, $4 \mathrm{ml}$ indicator dye was added to the test tube. Electrophoresis was performed using an 8\% polyacrylamide gel with 1:20 Tris-acetate-EDTA buffer at $120 \mathrm{~V}$ for $60 \mathrm{~min}$. The gel was stained with $0.5 \mathrm{mmol} / \mathrm{ml}$ ethidium bromide and imaged under ultraviolet light using a camera and Image Master software (Pharmacia Biotech, Tokyo, Japan). Electropherograms of the amplified products following restriction enzyme digestion were photographed and saved on digital media. Images were analyzed using Image Master software.

Statistical analysis. Statistical analysis was performed using univariate analysis of variance. An advanced regression model (general linear model) was used to evaluate the dependencies between multiple variables. Statistical analysis was performed using STATISTICA data analysis software system, version 10 (AXAP202E504303AR-A; StatSoft, Inc., Tulsa, OK, USA). In addition, the Bonferroni correction was used for the three tested polymorphisms. $\mathrm{P}<0.05$ was considered to indicate a statistically significant difference. Differences and linear trends between the three tested genotypes were identified. A haplotype effect model (additive and dominant) was used to analyze the haplotypes and haplotype-specific scores with the R statistics package (http://www.r-project.org/). Genotyping was performed by two investigators who were unaware of the phenotypes.

\section{Results}

In the test and control groups, the following values were identified for the studied variables: Beck (depression), STAI-I (state anxiety), STAI-II (trait anxiety) and Borg (breathlessness) scales, as presented in Table II.

The frequencies of occurrence of the polymorphic forms of NR3C1 are presented in Table III. The AA ER22/23EK, GG N363S and CC BclI alleles were identified to be rare forms of NR3Cl polymorphisms, while GG ER22/23EK, AA N363S and GG BclI were more frequent. Univariate analysis of the tested parameters revealed the existence of significant differences between the test and control groups, as shown in Table IV. 
Table II. Descriptive statistics of depression, anxiety and breathlessness in the healthy control and asthma patients.

\begin{tabular}{lrrrrrr} 
A, Controls & \multicolumn{1}{l}{} \\
\hline Parameter & Mean & Median & Mode & Min. & Max. & SD \\
\hline Beck scale & 8.34 & 6.00 & 2.00 & 0.00 & 33.00 & 7.14 \\
STAI-I & 36.95 & 35.00 & 1.00 & 20.00 & 62.00 & 9.29 \\
STAI-II & 41.54 & 41.00 & 1.00 & 21.00 & 63.00 & 9.06 \\
Borg scale & 1.74 & 1.00 & 0.00 & 0.00 & 8.00 & 1.89 \\
\hline
\end{tabular}

B, Cases

\begin{tabular}{lrrrrrr}
\hline Parameter & Mean & Median & Mode & Min. & Max. & SD \\
\hline Beck scale & 10.28 & 9.00 & 1.00 & 0.00 & 45.00 & 7.65 \\
STAI-I & 38.19 & 37.00 & 1.00 & 20.00 & 74.00 & 10.60 \\
STAI-II & 42.91 & 43.00 & 1.00 & 1.00 & 64.00 & 9.17 \\
Borg scale & 3.48 & 3.00 & 5.00 & 0.00 & 9.00 & 2.48 \\
\hline
\end{tabular}

STAI-I, state anxiety inventory; STAI-II, trait anxiety inventory; SD, standard deviation.

Table III. Frequencies of polymorphic forms of $N R 3 C 1$ in the healthy controls and asthma patients.

\begin{tabular}{lcr}
\hline $\begin{array}{l}\text { NR3C1 } \\
\text { polymorphic form }\end{array}$ & Controls (\%) & Cases (\%) \\
\hline ER22/23EK G & 96.74 & 97.22 \\
ER22/23EK A & 3.26 & 2.78 \\
N363S A & 86.74 & 87.45 \\
N363S G & 13.26 & 12.55 \\
BclI G & 58.80 & 57.05 \\
BclI C & 41.20 & 42.95 \\
\hline
\end{tabular}

Table IV. Associations between the variables in the test and control groups using univariate analysis of variance.

\begin{tabular}{lrccrr}
\hline Variable & SS & DF & MS & F & P-value \\
\hline Beck scale & 1285.840 & 2 & 642.920 & 12.107 & $<0.001$ \\
STAI-I & 307.600 & 2 & 153.800 & 1.526 & 0.218 \\
STAI-II & 443.500 & 2 & 221.700 & 2.676 & 0.070 \\
Borg scale & 387.139 & 2 & 193.569 & 40.220 & $<0.001$ \\
\hline
\end{tabular}

An overall analysis was performed for the two groups together. SS, sum of squares; DF, degrees of freedom; MS, mean square; $\mathrm{F}=\mathrm{MSM} / \mathrm{MSE}$; MSM, mean square model; MSE, mean square error; STA-I, state anxiety inventory; STA-II, trait anxiety inventory.

In the studied populations, a complex association was identified between the analyzed variables (depression, state and trait anxieties and breathlessness) and the results of the respiratory function tests. Table $\mathrm{V}$ presents detailed correla- tions divided into the two subgroups: Healthy subjects and asthma patients.

Functional assessments. Associations between the variables (depression, anxiety and breathlessness) and objective, measurable and repeatable spirometric parameters were analyzed. These results illustrated the degree of airway obstruction in the asthma patients with regard to the severity of the illness, as assessed by the ATS criteria, compared with the control group. A detailed analysis is presented in Table VI.

Haplotype analysis. The results of more advanced tests concerning the polymorphisms of the NR3Cl gene, which is located on the long arm of chromosome 5 at position q31-q32, are shown in Tables VII-X (42). The gene is inherited as a set of associated alleles, together with depression, anxiety and breathlessness. Haplotype analysis performed using the additive haplotype effects model [global statistic, 0.913; degrees of freedom (DF), 6; $\mathrm{P}=0.988$ ] did not reveal any correlations between the $\mathrm{NR} 3 \mathrm{Cl}$ gene haplotypes and depression, as shown in Table VII. In addition, haplotype analysis performed using the additive haplotype effects model (global statistic, 1.237; $\mathrm{DF}, 6 ; \mathrm{P}=0.974)$ revealed that no combinations of alleles were significantly associated with state-anxiety (Table VIII). However, haplotype analysis using the haplotype-specific stores did confirm a statistically significant association $(\mathrm{P}=0.026)$ with trait anxiety for one of the combinations of alleles, as shown in Table IX. Haplotype analysis performed using the additive haplotype effects model (global statistic, 6.195; DF, 6; $\mathrm{P}=0.401$ ) did not reveal an association between NR3Cl haplotypes and breathlessness, as shown in Table X. Therefore, haplotype analysis revealed a correlation between polymorphic forms of $\mathrm{NR} 3 \mathrm{Cl}$ and the level of trait-anxiety.

Correlation analysis. Scatter plots (Figs. 1 and 2) presented a graphical interpretation of the key correlations between trait-anxiety (STAI-II) and the spirometric parameters, FEV1 and FVC, for the following groups: Cases vs. controls.

\section{Discussion}

Research on the interaction between GCs and receptors is important for improving the understanding of asthma therapy. The use of GCs was a turning point in the history of the treatment of this disease. The NR3Cl gene and its transcripts are key factors involved in the inflammation of asthma and are responsible for alterations in the functioning of the GR (22-24). GCs are able to alter the regulation of $\mathrm{CRH}$, thus, affect the development of depression and anxiety disorders (22-24). Therefore, polymorphic forms of $\mathrm{NR} 3 \mathrm{Cl}$, which replicate the effect of the regulatory gene and affect the function of the promoter and the encoded protein (GR), can lead to the induction of depressive and anxiety disorders, and modify their intensity.

In the present study, a statistically significant correlation was observed between the levels of depression, anxiety (state and trait) and dyspnea with the spirometric parameters FEV1 and FVC. In addition, a correlation was observed between the FEV1:FVC respiratory function with depression and shortness of breath. These associations were observed in the asthma patients and control group. 
Table V. Advanced multivariate general regression models for depression, anxiety and breathlessness in the group of asthma patients compared with the healthy control group.

A, Depression (Beck scale)

\begin{tabular}{llr}
\hline $\begin{array}{l}\text { Spirometric } \\
\text { parameter }\end{array}$ & $\begin{array}{l}\text { Healthy } \\
\text { subjects }\end{array}$ & $\begin{array}{l}\text { Asthma } \\
\text { patients }\end{array}$ \\
\hline FEV1 (litre) & $\mathrm{r}=-0.2544$ & $\mathrm{r}=-0.3759$ \\
& $\mathrm{P}=0.0007$ & $\mathrm{P}<0.0001$ \\
& $\mathrm{r}^{2}=0.0647$ & $\mathrm{r}^{2}=0.1413$ \\
FVC (litre) & $\mathrm{r}=-0.2300$ & $\mathrm{r}=-0.3495$ \\
& $\mathrm{P}=0.0023$ & $\mathrm{P}<0.0001$ \\
FEV1:FVC (\%) & $\mathrm{r}^{2}=0.0529$ & $\mathrm{r}^{2}=0.1221$ \\
& $\mathrm{r}=-0.1069$ & $\mathrm{r}=-0.1876$ \\
& $\mathrm{P}=0.1615$ & $\mathrm{P}=0.0052$ \\
& $\mathrm{r}^{2}=0.0114$ & $\mathrm{r}^{2}=0.0352$ \\
\hline
\end{tabular}

B, State-anxiety (STAI-I)

\begin{tabular}{lll}
\hline $\begin{array}{l}\text { Spirometric } \\
\text { parameter }\end{array}$ & $\begin{array}{l}\text { Healthy } \\
\text { subjects }\end{array}$ & $\begin{array}{l}\text { Asthma } \\
\text { patients }\end{array}$ \\
\hline FEV1 (litre) & $\mathrm{r}=-0.1430$ & $\mathrm{r}=-0.1517$ \\
& $\mathrm{P}=0.0605$ & $\mathrm{P}=0.0244$ \\
& $\mathrm{r}^{2}=0.0205$ & $\mathrm{r}^{2}=0.0230$ \\
FVC (litre) & $\mathrm{r}=-0.1488$ & $\mathrm{r}=-0.2217$ \\
& $\mathrm{P}=0.0507$ & $\mathrm{P}=0.0009$ \\
FEV1:FVC $(\%)$ & $\mathrm{r}^{2}=0.0222$ & $\mathrm{r}^{2}=0.0491$ \\
& $\mathrm{r}=-0.0147$ & $\mathrm{r}=0.0893$ \\
& $\mathrm{P}=0.8482$ & $\mathrm{P}=0.1867$ \\
& $\mathrm{r}^{2}=0.0002$ & $\mathrm{r}^{2}=0.0080$ \\
\hline
\end{tabular}

C, Trait-anxiety (STAI-II)

\begin{tabular}{lll}
\hline $\begin{array}{l}\text { Spirometric } \\
\text { parameter }\end{array}$ & $\begin{array}{l}\text { Healthy } \\
\text { subjects }\end{array}$ & $\begin{array}{l}\text { Asthma } \\
\text { patients }\end{array}$ \\
\hline FEV1 (litre) & $\mathrm{r}=-0.2651$ & $\mathrm{r}=-0.2810$ \\
& $\mathrm{P}=0.0004$ & $\mathrm{P}<0.0001$ \\
& $\mathrm{r}^{2}=0.0703$ & $\mathrm{r}^{2}=0.0789$ \\
FVC (litre) & $\mathrm{r}=-0.2618$ & $\mathrm{r}=-0.3397$ \\
& $\mathrm{P}=0.0005$ & $\mathrm{P}<0.0001$ \\
FEV1:FVC (\%) & $\mathrm{r}^{2}=0.0686$ & $\mathrm{r}^{2}=0.1154$ \\
& $\mathrm{r}=-0.0500$ & $\mathrm{r}=0.0248$ \\
& $\mathrm{P}=0.5133$ & $\mathrm{P}=0.7142$ \\
& $\mathrm{r}^{2}=0.0025$ & $\mathrm{r}^{2}=0.0006$ \\
\hline
\end{tabular}

D, Breathlessness (Borg scale)

\begin{tabular}{lll}
\hline $\begin{array}{l}\text { Spirometric } \\
\text { parameter }\end{array}$ & $\begin{array}{l}\text { Healthy } \\
\text { subjects }\end{array}$ & $\begin{array}{l}\text { Asthma } \\
\text { patients }\end{array}$ \\
\hline FEV1 (litre) & $\mathrm{r}=-0.1948$ & $\mathrm{r}=-0.3202$ \\
& $\mathrm{P}=0.0107$ & $\mathrm{P}<0.0001$ \\
& $\mathrm{r}^{2}=0.0379$ & $\mathrm{r}^{2}=0.1025$
\end{tabular}

Table V. Continued

\begin{tabular}{llc}
\hline $\begin{array}{l}\text { Spirometric } \\
\text { parameter }\end{array}$ & $\begin{array}{l}\text { Healthy } \\
\text { subjects }\end{array}$ & $\begin{array}{c}\text { Asthma } \\
\text { sufferers }\end{array}$ \\
\hline FVC (litre) & $\mathrm{r}=-0.1506$ & $\mathrm{r}=-0.3048$ \\
& $\mathrm{P}=0.0493$ & $\mathrm{P}<0.0001$ \\
& $\mathrm{r}^{2}=0.0227$ & $\mathrm{r}^{2}=0.0929$ \\
FEV1:FVC $(\%)$ & $\mathrm{r}=-0.2194$ & $\mathrm{r}=-0.1512$ \\
& $\mathrm{P}=0.0039$ & $\mathrm{P}=0.0249$ \\
& $\mathrm{r}^{2}=0.0481$ & $\mathrm{r}^{2}=0.0229$ \\
\hline
\end{tabular}

FEV1, forced expiratory volume in $1 \mathrm{sec}$; FVC, forced vital capacity; FEV 1:FVC, ratio of FEV1 to FVC; $r$, linear correlation coefficient; $r^{2}$, multiple correlation coefficient squared; P, P-value.

Advanced analysis concerning the severity of asthma was performed by dividing the group of patients into two subgroups based on the ATS criteria. A correlation was observed between the level of depression in patients with severe asthma refractory to treatment and FEV1 ( $\mathrm{r}=-0.227, \mathrm{P}=0.048)$ and between the level of trait anxiety and FVC ( $\mathrm{r}=-0.321, \mathrm{P}=0.004)$. Similar observations were identified in asthma patients who did not meet the criteria of severe asthma refractory to treatment (depression vs. FEV1; depression vs. FVC; state-anxiety vs. FVC; state-anxiety vs. FEV1:FVC; trait-anxiety vs. FEV1, trait-anxiety vs. FVC; dyspnea vs. FEV1; dyspnea vs. FEV1; dyspnea vs. FVC; depression vs. FEV1:FVC).

A total of $24 \mathrm{NR} 3 \mathrm{Cl}$ gene variants were detected for each of the tested variables (depression, state and trait anxiety and breathlessness). Only one of the $N R 3 C 1$ haplotypes exhibited a correlation with state-anxiety $(\mathrm{P}=0.026)$, which was AA ER22/23EK (rare), AA N363S (common) and CC BclI (rare).

The ER22/23EK polymorphism is composed of two transition nucleotides at the $22^{\text {nd }}$ and $23^{\text {rd }}$ codons, which are connected with each other. SNPs may alter the secondary structure of the GR mRNA, and may consequently initiate translation from the $1^{\text {st }}$ or the $27^{\text {th }}$ methionine, as well as affect the stability of the mRNA $(26,32,33,43,44)$.

The presence of the N363S polymorphism promotes structural changes in the A/B region of the GR, affecting activation function-1 domain, which interacts with multiple transcription factors, as well as within the activator protein-1 functional domain $(25,26,45)$. The N363S polymorphism modulates numerous regulatory protein groups, decreases the activity of nuclear factor- $\kappa \mathrm{B}$ and stimulates the production of $\mathrm{I} \kappa \mathrm{B} \alpha$, thus, interfering with the suppression of IL-2 $(25,26,45)$.

The BclI SNP is coupled with two other polymorphic forms of NR3Cl: Intron B 33389 (rs33389) and Intron B 33388 (rs33388) $(27,46)$. These three polymorphisms modify the recognition site by alternative splicing of the $N R 3 C 1$ factors: SR (serine/arginine-rich protein) and SF2/ASF (splicing factor 2/alternative splicing factor) $(27,47)$.

The results of the present study confirm previous observations that changes, including depression, anxiety and breathlessness, significantly correlate with spirometric parameters and have an influence on the severity of the course of asthma $(4,37)$. The present study characterizes and precisely 
Table VI. Advanced multivariate general regression models for depression, anxiety and breathlessness in the asthma patient group compared with the control group, with regard to the severity of asthma.

A, Depression (Beck scale)

\begin{tabular}{lccc}
\hline $\begin{array}{l}\text { Spirometric } \\
\text { parameter }\end{array}$ & Healthy & ATS 0 & ATS 1 \\
\hline FEV1 (litre) & $\mathrm{r}=-0.2544$ & $\mathrm{r}=-0.3630$ & $\mathrm{r}=-0.2273$ \\
& $\mathrm{P}=0.0007$ & $\mathrm{P}<0.0001$ & $\mathrm{P}=0.0483$ \\
& $\mathrm{r}^{2}=0.0647$ & $\mathrm{r}^{2}=0.1318$ & $\mathrm{r}^{2}=0.0517$ \\
FVC (litre) & $\mathrm{r}=-0.2300$ & $\mathrm{r}=-0.3687$ & $\mathrm{r}=-0.2099$ \\
& $\mathrm{P}=0.0023$ & $\mathrm{P}<0.0001$ & $\mathrm{P}=0.0688$ \\
& $\mathrm{r}^{2}=0.0529$ & $\mathrm{r}^{2}=0.1360$ & $\mathrm{r}^{2}=0.0441$ \\
FEV1:FVC (\%) & $\mathrm{r}=-0.1069$ & $\mathrm{r}=-0.0686$ & $\mathrm{r}=-0.1422$ \\
& $\mathrm{P}=0.1615$ & $\mathrm{P}=0.4139$ & $\mathrm{P}=0.2204$ \\
& $\mathrm{r}^{2}=0.0114$ & $\mathrm{r}^{2}=0.0047$ & $\mathrm{r}=0.0202$
\end{tabular}

B, State anxiety (STAI-I)

\begin{tabular}{lccc}
\hline $\begin{array}{l}\text { Spirometric } \\
\text { parameter }\end{array}$ & Healthy & ATS 0 & ATS 1 \\
\hline FEV1 (litre) & $\mathrm{r}=-0.1430$ & $\mathrm{r}=-0.1552$ & $\mathrm{r}=-0.0805$ \\
& $\mathrm{P}=0.0605$ & $\mathrm{P}=0.0633$ & $\mathrm{P}=0.4895$ \\
& $\mathrm{r}^{2}=0.0205$ & $\mathrm{r}^{2}=0.0241$ & $\mathrm{r}^{2}=0.0065$ \\
FVC (litre) & $\mathrm{r}=-0.1488$ & $\mathrm{r}=-0.2183$ & $\mathrm{r}=-0.1899$ \\
& $\mathrm{P}=0.0507$ & $\mathrm{P}=0.0086$ & $\mathrm{P}=0.1003$ \\
& $\mathrm{r}^{2}=0.0222$ & $\mathrm{r}^{2}=0.0476$ & $\mathrm{r}^{2}=0.0361$ \\
FEV1:FVC (\%) & $\mathrm{r}=0.0767$ & $\mathrm{r}=0.1753$ & $\mathrm{r}=0.1775$ \\
& $\mathrm{P}=0.3156$ & $\mathrm{P}=0.0356$ & $\mathrm{P}=0.1250$ \\
& $\mathrm{r}^{2}=0.0059$ & $\mathrm{r}^{2}=0.0307$ & $\mathrm{r}^{2}=0.0315$
\end{tabular}

C, Trait anxiety (STAI-II)

\begin{tabular}{lccc}
$\begin{array}{l}\text { Spirometric } \\
\text { parameter }\end{array}$ & Healthy & ATS 0 & ATS 1 \\
\hline FEV1 (litre) & $\mathrm{r}=-0.2651$ & $\mathrm{r}=-0.2724$ & $\mathrm{r}=-0.2186$ \\
& $\mathrm{P}=0.0004$ & $\mathrm{P}=0.0010$ & $\mathrm{P}=0.0578$ \\
& $\mathrm{r}^{2}=0.0703$ & $\mathrm{r}^{2}=0.0742$ & $\mathrm{r}^{2}=0.0478$ \\
FVC (litre) & $\mathrm{r}=-0.2618$ & $\mathrm{r}=-0.3221$ & $\mathrm{r}=-0.3210$ \\
& $\mathrm{P}=0.0005$ & $\mathrm{P}<0.0001$ & $\mathrm{P}=0.0047$ \\
& $\mathrm{r}^{2}=0.0686$ & $\mathrm{r}^{2}=0.1038$ & $\mathrm{r}^{2}=0.1031$ \\
FEV1:FVC (\%) & $\mathrm{r}=0.0519$ & $\mathrm{r}=0.1093$ & $\mathrm{r}=0.1400$ \\
& $\mathrm{P}=0.4977$ & $\mathrm{P}=0.1923$ & $\mathrm{P}=0.2276$ \\
& $\mathrm{r}^{2}=0.0027$ & $\mathrm{r}^{2}=0.0119$ & $\mathrm{r}^{2}=0.0196$ \\
\hline
\end{tabular}

D, Breathlessness (Borg scale)

\begin{tabular}{lccc}
\hline $\begin{array}{l}\text { Spirometric } \\
\text { parameter }\end{array}$ & Healthy & ATS 0 & ATS 1 \\
\hline FEV1 (litre) & $\mathrm{r}=-0.1948$ & $\mathrm{r}=-0.3043$ & $\mathrm{r}=-0.1254$ \\
& $\mathrm{P}=0.0107$ & $\mathrm{P}=0.0002$ & $\mathrm{P}=0.2773$ \\
& $\mathrm{r}^{2}=0.0379$ & $\mathrm{r}^{2}=0.0926$ & $\mathrm{r}^{2}=0.0157$
\end{tabular}

Table VI. Continued

\begin{tabular}{lccc}
\hline $\begin{array}{l}\text { Spirometric } \\
\text { parameter }\end{array}$ & Healthy & ATS 0 & ATS 1 \\
\hline FVC (litre) & $\mathrm{r}=-0.1506$ & $\mathrm{r}=-0.2907$ & $\mathrm{r}=-0.1909$ \\
& $\mathrm{P}=0.0493$ & $\mathrm{P}=0.0004$ & $\mathrm{P}=0.0963$ \\
& $\mathrm{r}^{2}=0.0227$ & $\mathrm{r}^{2}=0.0845$ & $\mathrm{r}^{2}=0.0365$ \\
FEV1:FVC $(\%)$ & $\mathrm{r}=-0.2194$ & $\mathrm{r}=-0.1256$ & $\mathrm{r}=0.0500$ \\
& $\mathrm{P}=0.0039$ & $\mathrm{P}=0.1350$ & $\mathrm{P}=0.6656$ \\
& $\mathrm{r}^{2}=0.0481$ & $\mathrm{r}^{2}=0.0158$ & $\mathrm{r}^{2}=0.0025$ \\
\hline
\end{tabular}

ATS 0, patients with asthma, but not fulfilling the criteria of severe asthma refractory to treatment according to the ATS guidelines; ATS 1, suffering from asthma and fulfilling the criteria of severe asthma refractory to treatment according to the ATS guidelines; FEV1, forced expiratory volume in $1 \mathrm{sec}$; FVC, forced vital capacity; FEV1:FVC, ratio of FEV1 to FVC; $r$, linear correlation coefficient; $\mathrm{r}^{2}$, multiple correlation coefficient squared; ATS, American Thoracic Society; P, P-value.

Table VII. Haplotype-specific scores for depression using the haplotype effects model.

\begin{tabular}{|c|c|c|c|c|c|}
\hline \multicolumn{3}{|c|}{ Genotype } & \multicolumn{2}{|c|}{ Haplotype } & \multirow[b]{2}{*}{ P-value } \\
\hline $\begin{array}{l}\text { ER22 } \\
\text { /23EK }\end{array}$ & N363S & BclI & Frequency & Score & \\
\hline GG & GG & GG & 0.05797 & -0.88383 & 0.37679 \\
\hline GG & $\mathrm{AA}$ & $\mathrm{CC}$ & 0.39565 & -0.71309 & 0.47579 \\
\hline GG & GG & $\mathrm{CC}$ & 0.02783 & -0.24739 & 0.80461 \\
\hline AA & $\mathrm{AA}$ & GG & 0.02235 & 0.36511 & 0.71503 \\
\hline AA & $\mathrm{AA}$ & $\mathrm{CC}$ & 0.00725 & 0.63020 & 0.52856 \\
\hline GG & $\mathrm{AA}$ & GG & 0.48776 & 0.97533 & 0.32940 \\
\hline
\end{tabular}

describes the haplotypes of the $N R 3 C 1$ gene, while identifying the haplotype responsible for the changes occurring in trait-anxiety in asthma sufferers. The results demonstrated that trait-anxiety significantly lowered a number of spirometric parameters (FEV1, FVC, FEV1:FVC), causing a more severe course of illness. Previous studies on NR3Cl gene polymorphisms have failed to confirm that the ER22/23EK and BclI SNPs play any role in the etiopathogenesis of asthma. The results of the current study confirmed that all NR3C1 polymorphisms (haplotype, ER22/23EK, N363S and BclI) participate in the regulation of the intensity of trait-anxiety in asthma patients, which significantly correlates with increases in airflow obstruction $(4,25,26,37,48)$. The association between $\mathrm{NR} 3 \mathrm{Cl}$ haplotypes with depression and anxiety may therefore be complex. The same polymorphism which influences the development of asthma and the degree of severity can function indirectly as a stressor (airway obstruction), inducing depression and anxiety disorders. This observed phenomenon may also explain the differences in the functioning of the GR associated with the decreased expression of multiple proteins in the brain. Co-occurrence of asthma, mood disorders and 
Table VIII. Haplotype-specific scores for STAI-I using the haplotype effects model.

\begin{tabular}{lllllll}
\hline \multicolumn{3}{c}{ Genotype } & & & \multicolumn{2}{c}{ Haplotype } \\
\cline { 1 - 1 } ER22 & & & & & \\
l23EK & N363S & BclI & & Frequency & Score & P-value \\
\hline GG & AA & CC & & 0.39565 & -0.63527 & 0.52525 \\
GG & GG & GG & & 0.05797 & -0.57593 & 0.56466 \\
AA & AA & CC & & 0.00725 & -0.29875 & 0.76513 \\
AA & AA & GG & & 0.02235 & -0.22619 & 0.82106 \\
GG & GG & CC & & 0.02783 & 0.01604 & 0.98720 \\
GG & AA & GG & 0.48776 & 0.98623 & 0.32402 \\
\hline
\end{tabular}

STAI-I, state-anxiety inventory.

Table IX. Haplotype-specific scores for STAI-II using the haplotype effects model.

\begin{tabular}{lllllll}
\hline \multicolumn{3}{c}{ Genotype } & & \multicolumn{2}{c}{ Haplotype } & \\
\cline { 1 - 1 } ER22 & & & & & \\
/23EK & N363S & BclI & & Frequency & Score & P-value \\
\hline GG & AA & CC & & 0.39565 & -1.21509 & 0.22433 \\
GG & GG & GG & & 0.05797 & -1.0306 & 0.30273 \\
AA & AA & GG & & 0.02235 & -1.01922 & 0.30810 \\
GG & GG & CC & & 0.02783 & 0.63846 & 0.52317 \\
GG & AA & GG & & 0.48776 & 1.53739 & 0.12420 \\
AA & AA & CC & 0.00725 & 2.21614 & 0.02668 \\
\hline
\end{tabular}

STAI-II, trait-anxiety inventory.

Table X. Haplotype-specific stores for breathlessness using the haplotype effects model.

\begin{tabular}{lcccccc}
\hline \multicolumn{3}{c}{ Genotype } & & \multicolumn{2}{c}{ Haplotype } & \\
\cline { 1 - 1 } ER22 & & & & & \\
I23EK & N363S & BclI & Frequency & Score & P-value \\
\hline GG & GG & GG & & 0.05998 & -1.20047 & 0.22995 \\
AA & AA & CC & & 0.00720 & -0.89380 & 0.37143 \\
AA & AA & GG & & 0.02255 & -0.76096 & 0.44668 \\
GG & AA & CC & & 0.39722 & -0.67443 & 0.50004 \\
GG & GG & CC & & 0.02741 & 0.92493 & 0.35500 \\
GG & AA & GG & 0.48451 & 1.33597 & 0.18156 \\
\hline
\end{tabular}

anxiety may stem from a common genetic cause; this has been indirectly confirmed by the evidence that gene polymorphisms are associated with the occurrence of $\mathrm{NR} 3 \mathrm{Cl}$ mood disorders, and also that the HPA axis is involved in the pathogenesis of depression.

Therefore, the gene encoding $\mathrm{NR} 3 \mathrm{Cl}$ GR activity is an important regulator of the biochemical and molecular mecha-

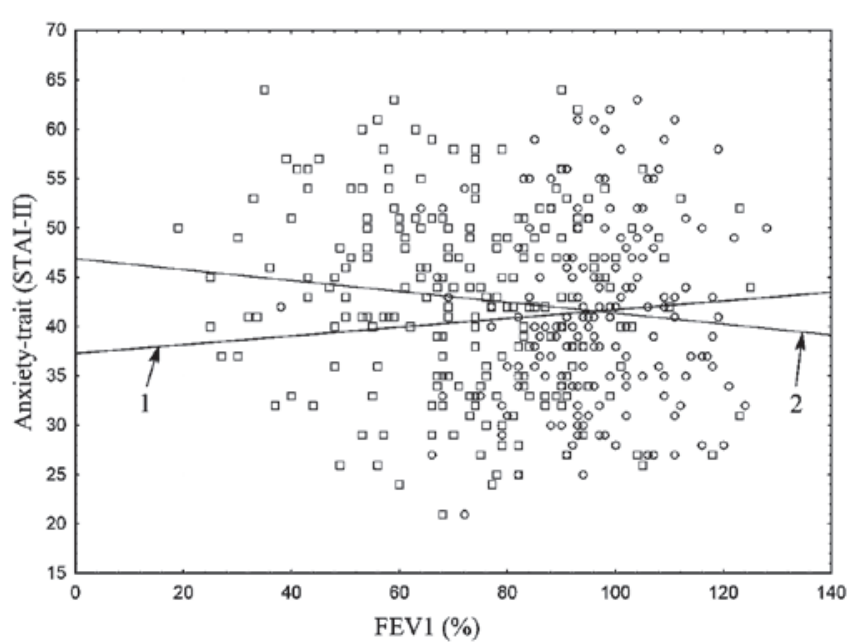

Figure 1. Correlation between STAI-II and FEV1 (\%) for the cases and controls. Line 1 (circles), healthy controls; line 2 (squares), asthma patients; FEV1, forced expiratory volume in $1 \mathrm{sec}$; STAI-II, trait-anxiety inventory.

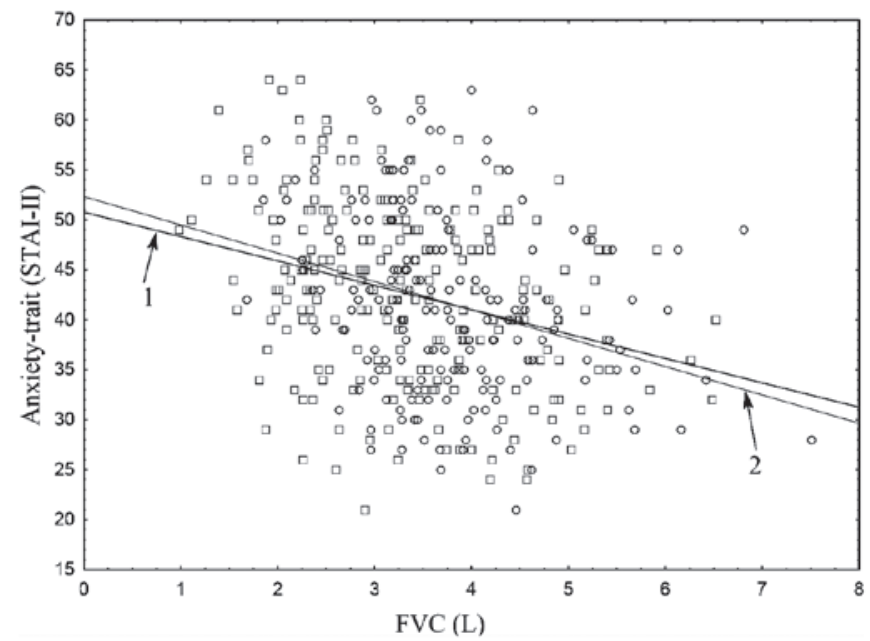

Figure 2. Correlation between STAI-II and FVC for the cases and controls. Line 1 (circles), healthy controls; line 2 (squares), asthma patients; FVC, forced vital capacity; STAI-II, trait-anxiety inventory.

nisms involved in the changes of the GR, thus, affects the degree of airway obstruction. The haplotype, ER22/23EK, N363S and BclI, materially affects, directly or indirectly, psychopathological and personality variables, including depression, anxiety and shortness of breath $(4,25,26,37,48)$.

Furthermore, the present study highlights the under diagnosis of affective and anxiety disorders among asthma sufferers.

However, the present study has limitations associated with asthma medication treatment. This group of medicines comprises inhaled and systematic glucocorticosteroids, which can induce depression. Therefore, patients experiencing asthma attacks, which required the use of glucocorticosteroids, were excluded from the study. In addition, the test and the control group did not include subjects who were receiving long-term systematic glucocorticosteroid treatment for any other medical conditions. 
For the subjects included in the study, the diagnosis of depression and anxiety disorders was performed for the first time. Thus, it was difficult to further assess the clinical course of the affective and anxiety disorders. Patients who had previously been treated for anxiety disorders and depression were not included in the study.

In conclusion, a multivariate study analyzing the role of genetic variants in the $\mathrm{NR} 3 \mathrm{Cl}$ gene was performed in patients with asthma, with particular emphasis on the intensity of their depression, anxiety and shortness of breath.

The results demonstrated that the haplotypic variations in the regulatory regions of the $N R 3 C 1$ gene significantly correlated with trait-anxiety. In addition, important molecular mechanisms leading to the development of depression and anxiety in asthma patients were identified, and correlations that existed with functional spirometry parameters were indicated.

NR3Cl polymorphisms and haplotypes are general modulating factors of the level of depression, shortness of breath and anxiety, which significantly predispose patients with asthma to the development of affective disorders and anxiety.

\section{Acknowledgements}

The study was supported by a grant from the Minister of Science and Higher Education of the Polish Republic (no. N N402 374638). In addition, the study was supported by a grant within the framework of a project supporting innovative doctoral studies, entitled: 'Scholarships supporting innovative doctoral studies', based on funds provided by the EU European Social Fund and Polish state budget allocation for the Integrated Operational Plan for Regional Development according to Lodz Region Innovation Strategy-RSI LORIS (program title, ZPORR; sector, 2.6 Regional Innovation Strategies and Transfer of Knowledge; project no. Z/2.10/ II/2.6/1/09). This project was financed $75 \%$ by the European Social Fund and $25 \%$ by the state budget. The study was also financed by a fund from the Department of Internal Medicine, Asthma and Allergy, $2^{\text {nd }}$ Chair of Internal Medicine, Medical University of Lodz, Poland (no. 503/1-095-03/503-01). The authors thank Damian Tworek MD-PhD for assistance with patient recruitment and blood collection, Joanna Molinska MA for assistance with administration and Ms. Beata Małachowska for assistance with statistical analysis. Beata Małachowska was supported by the TEAM project financed by the Innovative Economy Operational Program and coordinated by the Foundation for Polish Science. Finally, the authors thank all those who provided assistance during the completion of the study.

\section{References}

1. Kessler RC, McGonagle KA, Zhao S, et al: Lifetime and 12 -month prevalence of DSM-III-R psychiatric disorders in the United States. Results from the National Comorbidity Survey. Arch Gen Psychiatry 51: 8-19, 1994.

2. de Miguel Diez J, García RJ, Hernandez Barrera V, et al: Mental health among adults with asthma and chronic bronchitis. A population-based study in Spain. Respir Med 106: 924-932, 2012.

3. Wang ZL: Evolving role of systemic inflammation in comorbidities of chronic obstructive pulmonary disease. Chin Med J (Engl) 123: 3467-3478, 2010
4. Pietras T, Panek M, Witusik A, et al: Analysis of the correlation between level of anxiety, intensity of depression and bronchial asthma control. Post Dermatol Alergol 28: 15-22, 2011.

5. Strelau J: Psychology of temperament. PWN, Warsaw, 2009 (In Polish).

6. Strelau J: Temperament, personality, activity. Academic Press, London, 1983.

7. Strelau J: The Psychology of individual differences. Scholar, Warsaw, 2006 (In Polish)

8. Sęk H: Introduction to Clinical Psychology. Scholar, Warsaw, 2001 (In Polish).

9. Marques AH, Silverman MN and Sternberg EM: Glucocorticoid dysregulations and their clinical correlates. From receptors to therapeutics. Ann N Y Acad Sci 1179: 1-18, 2009.

10. Margaretten M, Julian L, Katz P and Yelin E.: Depression in patients with rheumatoid arthritis: description, causes and mechanisms. Int J Clin Rheumtol 6: 617-623, 2011.

11. Jacobson L: Hypothalamic-pituitary-adrenocortical axis regulation. Endocrinol Metab Clin North Am 34: 271-292, 2005.

12. Elomaa AP, Niskanen L, Herzig KH, et al: Elevated levels of serum IL-5 are associated with an increased likelihood of major depressive disorder. BMC Psychiatry 12: 2, 2012.

13. Favreau H, Bacon SL, Joseph M, et al: Association between asthma medications and suicidal ideation in adult asthmatics. Respir Med 106: 933-941, 2012.

14. Pace TW, Hu F and Miller AH: Cytokine-effects on glucocorticoid receptor function: relevance to glucocorticoid resistance and the pathophysiology and treatment of major depression. Brain Behav Immun 21: 9-19, 2007.

15. Irwin MR and Miller AH: Depressive disorders and immunity: 20 years of progress and discovery. Brain Behav Immun 21: 374-383, 2007.

16. Khairova RA, Machado-Vieira R, Du J and Manji HK: A potential role for pro-inflammatory cytokines in regulating synaptic plasticity in major depressive disorder. Int $\mathbf{J}$ Neuropsychopharmacol 12: 561-578, 2009.

17. Denayer E, Ahmed T, Brems H, et al: Spred1 is required for synaptic plasticity and hippocampus-dependent learning. J Neurosci 28: 14443-14449, 2008.

18. Heim MH: The Jak-STAT pathway: specific signal transduction from the cell membrane to the nucleus. Eur J Clin Invest 26: 1-12, 1996.

19. Zambrano A, Otth C, Maccioni RB and Concha II: IL-3 controls tau modifications and protects cortical neurons from neurodegeneration. Curr Alzheimer Res 7: 615-624, 2010.

20. Hu F, Pace TW and Miller AH: Interferon-alpha inhibits glucocorticoid receptor-mediated gene transcription via STAT5 activation in mouse HT22 cells. Brain Behav Immun 23: 455-463, 2009.

21. Owens MJ and Nemeroff CB: Physiology and pharmacology of corticotropin-releasing factor. Pharmacol Rev 43: 425-473, 1991.

22. Raison CL and Miller AH: When not enough is too much: The role of insufficient glucocorticoid signaling in the pathophysiology of stress-related disorders. Am J Psychiatry 160: 1554-1565, 2003.

23. Raison CL, Capuron L and Miller AH: Cytokines sing the blues: inflammation and the pathogenesis of depression. Trends Immunol 27: 24-31, 2006.

24. Pariante CM and Miller AH: Glucocorticoid receptors in major depression: relevance to pathophysiology and treatment. Biol Psychiatry 49: 391-404, 2001.

25. Panek M, Pietras T, Antczak A, et al: The N363S and I559N single nucleotide polymorphisms of the $\mathrm{h}-\mathrm{GR} / \mathrm{NR} 3 \mathrm{C} 1$ gene in patients with bronchial asthma. Int J Mol Med 30: 142-150, 2012.

26. Panek M, Pietras T, Antczak A, et al: The role of functional single nucleotide polymorphisms of the human glucocorticoid receptor gene NR3C1 in Polish patients with bronchial asthma. Mol Biol Rep 39: 4749-4757, 2012.

27. Stevens A, Ray DW, Zeggini E, et al: Glucocorticoid sensitivity is determined by a specific glucocorticoid receptor haplotype. J Clin Endocrinol Metab 89: 892-897, 2004.

28. Nicolaides NC, Galata Z, Kino T, et al: The human glucocorticoid receptor: molecular basis of biologic function. Steroids 75 : $1-12,2010$.

29. Bray PJ and Cotton RG: Variations of the human glucocorticoid receptor gene (NR3C1): pathological and in vitro mutations and polymorphisms. Hum Mutat 21: 557-568, 2003.

30. DeRijk RH, Schaaf M and de Kloet ER: Glucocorticoid receptor variants: clinical implications. J Steroid Biochem Mol Biol 81: 103-122, 2002. 
31. Ito K, Chung KF and Adcock IM: Update on glucocorticoid action and resistance. J Allergy Clin Immunol 117: 522-543, 2006.

32. van Rossum EF, Voorhoeve PG, te Velde SJ, et al: The ER22/23EK polymorphism in the glucocorticoid receptor gene is associated with a beneficial body composition and muscle strength in young adults. J Clin Endocrinol Metab 89: 4004-4009, 2004.

33. Bulas M, Trelińska J, Stolarska M, et al: Association of steroid receptor gene (NR3C1) polymorphism with clinical course of lymphoproliferative disorders in children - preliminary results. Onkol Pol 2: 77-81, 2008.

34. Miller M, Hankinson J, Brusasco V, et al; ATS/ERS Task Force: Standardisation of spirometry. Eur Respir J 26: 319-338, 2005.

35. Beck AT, Ward CH, Mendelson M, et al: An inventory for measuring depression. Arch Gen Psychiatry 4: 561-571, 1961.

36. Pużyński S and Wciórka J: The tools of mental state assessment In: Bilikiewicz A Pużyński S, Rybakowski J, editors. Psychiatry. Medical Publisher Urban \& Partner, Wrocław, pp453-538, 2002 (In Polish).

37. Pietras T, Panek M, Witusik A, et al: Analysis of the correlation between anxiety, depression, intensity of dyspnoea and severity of the bronchial asthma disease process. Post Dermatol Alergol 27: 390-399, 2010

38. Wrześniewski K, Sosnowski T and Matusik D: Inventory of State and Trait Anxiety STAI. Polish adaptation of STAI. Handbook. Laboratory of Psychological Tests of The Polish Psychological Association, Warsaw, 2002 (In Polish).

39. Grammatopoulou E, Skordilis E, Koutsouki D and Baltopoulos G: An 18-item standardized asthma quality of life questionnaire-AQLQ(S). Qual Life Res 17: 323-332, 2008.

40. Szabó V, Borgulya G, Filkorn T, et al: The variant N363S of glucocorticoid receptor in steroid-induced ocular hypertension in Hungarian patients treated with photorefractive keratectomy. Mol Vis 13: 659-666, 2007.
41. Majnik J, Patócs A, Balogh K, et al: A rapid and simple method for detection of Asn363Ser polymorphism of the human glucocorticoid receptor gene. J Steroid Biochem Mol Biol 92: 465-468, 2004.

42. Kino T, De Martino MU, Charmandari E, et al: Tissue glucocorticoid resistance/hypersensitivity syndromes. J Steroid Biochem Mol Biol 85: 457-467, 2003.

43. van Rossum EF and Lamberts SW: Polymorphisms in the glucocorticoid receptor gene and their associations with metabolic parameters and body composition. Recent Prog Horm Res 59: 333-357, 2004.

44. de Lange P, Koper JW, Huizenga NA, et al: Differential hormone-dependent transcriptional activation and -repression by naturally occurring human glucocorticoid receptor variants. Mol Endocrinol 11: 1156-1164, 1997.

45. Grzanka A and Rogala B: Molecular mechanism of glucocorticoids and difficult asthma. Allerg Asthma Immunol 5: 247-252, 2000.

46. Derijk R and de Kloet E: Corticosteroid receptor polymorphisms: determinants of vulnerability and resilience. Eur J Pharmacol 583: 303-311, 2008.

47. Pietras T, Panek M, Tworek D, et al: The BclI single nucleotide polymorphism of the human glucocorticoid receptor gene h-GR/NR3C1 promoter in patients with bronchial asthma: pilot study. Mol Biol Rep 38: 3953-3958, 2011.

48. Panek M, Pietras T, Fabijan A, et al: Effect of glucocorticoid receptor gene polymorphisms on asthma phenotypes. Exp Ther Med 5: 572-580, 2013 